\title{
KETELADANAN YESUS SEBAGAI GEMBALA MENJADI DASAR PELAYANAN HAMBA TUHAN MASA KINI
}

\author{
Herlince Rumahorbo \\ Sekolah Tinggi Teologi Injili Arastamar (SETIA) Jakarta \\ ajaherlin237@gmail.com
}

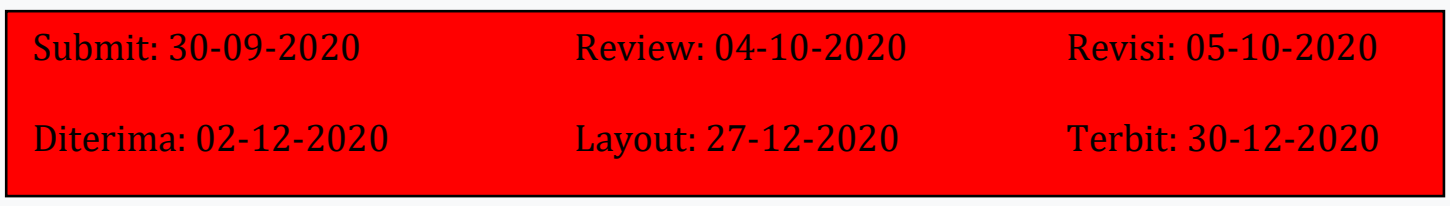

\begin{abstract}
This paper aims to explain the importance of an example in serving God. Exemplary is the foundation or foundation of someone who is involved in ministry. Good ministry in the family, church, school, community and country. Without an example of life, the ministry of a servant of God will be useless and have no impact. Jesus has left an example of obedience, loyalty, sincerity, self-sacrifice, caring and other virtues. He demands that His people, especially His servants, follow His example in shepherding His people. The work of serving God knows no limits and no time. It transcends time, money and power. Therefore, seriousness and seriousness and responsibility become a cross that is carried by a servant of God. God has chosen, appointed and sent a shepherd to feed, care for, protect from harm, and care for his sheep. Likewise, a servant of God treats His people not the other way around. This paper aims: 1) to provide understanding and emphasis that a shepherd is God's choice, therefore he must make God his example. 2) Shepherding God's people sincerely and lovingly will please God. 3) Servants of God can be accountable for the completion of their duties to God when He calls them back to Him
\end{abstract}

\section{Keywords: Shepherd, shepherd, His people}

\begin{abstract}
Abstrak
Tulisan ini bertujuan untuk memaparkan akan pentingnya sebuah keteladanan dalam melayani Tuhan. Keteladanan adalah dasar atau pondasi dari seseorang yang terlibat dalam pelayanan. Baik pelayanan di keluarga, gereja, sekolah, masyarakat dan negara. Tanpa keteladanan hidup, pelayanan seorang hamba Tuhan tidak akan berguna dan berdampak. Yesus telah meninggalkan sebuah keteladanan ketaataan, kesetiaan, ketulusan, rela berkorban, peduli dan kebajikan lainnya. Ia menuntut umat-Nya khusus hamba-Nya mengikuti teladan-Nya dalam mengembalakan umat-Nya. Pekerjaan melayani Tuhan tidak mengenal batas dan waktu. Ia menembus waktu, dana dan daya. Karena itu keseriusan dan kesungguhan serta tanggungjawab menjadi salib yang dipikul seorang hamba Tuhan. Tuhan telah memilih, menetapkan dan mengutus seorang gembala untuk memberi makan, merawat, melindungi dari bahaya, dan memelihara dombanya. Demikian pulalah seorang hamba Tuhan memperlakukan umat-Nya bukan sebaliknya. Tulisan ini bertujuan: 1) memberi pemahaman dan penekanan bahwa seorang gembala adalah pilihan Tuhan karena itu ia harus menjadikan Tuhan sebagai teladannya. 2) Menggembalakan umat Tuhan dengan tulus dan penuh kasih akan menyenangkan hati Tuhan. 3) Hamba Tuhan dapat mempertanggungjawabkan penyelesaian tugasnya kepada Tuhan ketika Ia memanggilnya kembali pada-Nya.
\end{abstract}

Kata kunci: Gembala, mengembalakan, umat-Nya 


\section{Pendahuluan}

Pada masa pandemi Covid-19, pelayanan dan pendapatan hamba Tuhan mengalami kendala yang signifikan. Tidak saja di daerah perkotaan melainkan pedesaan. Peraturan pemerintah memperingatkan semua umat untuk membatasi diri dalam hubungan sosial. Dimana sebelum Covid-19 dialami oleh dunia, khususnya di Indonesia, para hamba Tuhan leluasa melakukan tugas pelayanannya, yakni berkhotbah di depan jemaat, perkunjungan ibadah rumah tangga, pelayanan orang Sakit, rekreasi, dan kegiatan rohani lainnya. Namun, setelah masa pandemi covid-19, semua pelayanan terhenti dan terkendala. Situasi dan kondisi demikian, tidak sedikit hamba Tuhan yang pergi mengasingkan diri atau mengerjakan pekerjaan lain guna mengisi hari-hari kehidupannya. Ia dipenuhi dengan rasa was-was dan berusaha untuk tidak berkerumun sesuai dengan peraturan pemerintah. Namun, masih ada hamba Tuhan yang mengupayakan pelayanan dengan cara daring dan merekam khotbah. Hamba Tuhan harus menunjukkan keteladanannya dalam segala situasi. Bahkan hamba Tuhan juga dapat menangkap kondisi covid-19 ini sebagai kesempatan untuk melayani yang terhilang, tersesat dan kehilangan pengharapan. Ia dapat memodifikasi pelayanan dengan berbagai cara dengan tanpa tatap muka. Asalkan umat Tuhan memiliki persekutuan dengan Tuhan

'Dalam kehidupan sehari-hari dapat diamati bahwa kawanan domba dapat hidup, bergerak dan berkembang biak atas pendampingan yang tulus dan serius dari gembalanya. Gembalanya tahu kondisi dan keadaan domba karena ia bersama-sama dengan domba tersebut. Contoh nyata yang dapat dilihat bahwa domba, kambing, kerbau, sapi, ayam, babi, dan hewan peliharaan lainnya tidak dapat hidup bertahan dan hidup secara teratur tanpa tuntunan seorang gembala. Ia akan selalu berada di samping hewan tersebut, berada di posisi belakang dan depan mereka. Seorang Gembala selalu berusaha meyakinkan bahwa peliharaannya dalam kondisi kenyang, aman, tentram dan nyaman tanpa gangguan apapun.

Masa kini adalah masa pengujian dan penyucian hati seorang gembala. Dimana ia dipersiapkan menjadi bapa buat gembalaanya. Ia selalu memikirkan bagaimana kawanan domba selamat dari wabah covid-19 yang kecil, tidak kelihatan tapi berbahaya. Dan bila umat Tuhan terpapar virus corona, Gembala harus berdiri dan memberi kekuatan dan penghiburan. Ia juga mengupayakan supaya domba menjadi gemuk, sehat dan berkembang biak. Ia akan menjaga dombanya dari serangan binatang buas bahkan merawat mereka bila mengalami luka, sakit dan tidak berdaya. Suka duka domba terletak di tangan gembala tersebut. Bila hamba Tuhan tidak serius mengurus jemaat tersebut dengan baik dan benar, mereka akan tercerai berai dan Tuhan akan murka.

Pekerjaan gembala tidak dikagumi oleh banyak orang karena memerlukan pengorbanan waktu, tenaga dan dana. Bahkan mereka jauh dari kesenangan kehidupan orang pada umumnya. Dimana gembala lebih banyak bergaul dengan hewan peliharaannya di padang daripada berkumpul dengan orang banyak. Air yang cukup, rumput yang hijau dan tongkat menjadi assesoris dari seorang gembala. Juga memperaruhkan nyawa demi keselamatan domba-dombanya.

Dalam Alkitab, terang benderang dijelaskan ciri khas seorang gembala yang baik dan tidak baik. Ada beberapa tokoh yang dituliskan dalam Alkitab yang berprofesi sebagai gembala yaitu Kain, Abraham, Isak,Yakub, bahkan sampai Daud seorang raja Israel. Daud mengawali kariernya dengan menjadi seorang gembala.

Tuhan juga menyatakan bahwa semua nabi dan para imam adalah gembala yang diutus-Nya untuk menggembalakan umat-nya Israel. Tuhan menginginkan agar para gembala yang diutus melayani umat-Nya dengan tekun dan benar-benar memperhatikan apa yang salah dan memberikan ajaran yang benar kepada umat Israel. 
Gembala tidak hanya melihat kawanan yang ada di depannya tetapi ada pekerjaan lain yang Tuhan inginkan dari seorang gembala yaitu keteladanan dan tanggungjawab.

Dalam Yehezkiel 34, Tuhan menunjukkan ciri-ciri gembala yang baik dan tidak baik. Tuhan sangat menentang para gembala yang hidup tidak memperhatikan kawanan domba Allah yang dipercayakan kepadanya. Tuhan menempatkan gembala untuk memperhatikan kondisi mereka, namun ada gembala yang tidak menjaga domba melainkan memanfaatkan domba itu untuk keuntungan dirinya sendiri. Kata memanfaatkan memberi arti bahwa gembala hanya mengambil susu dan bulu domba tanpa tanpa harus mengurusnya.Tuhan sangat murka dan ingin menghukum para gembala yang tidak menunjukkan jalan yang sebenarnya kepada umat-Nya.

G. R. Beasley-Murray menuliskan gambaran penguasa di Israel yang memerintah di Israel pada saat-saat mendekati pembuangan ke Babel. ${ }^{1}$ Para penguasa yang ada pada saat itu digambarkan sebagai gembala yang tidak lagi memperhatikan keadaan para umat Tuhan yang dipercayakan kepada mereka untuk digembalakan.

Dalam Perjanjian Baru, Tuhan Yesus juga menyatakan para murid-Nya sebagai gembala dan orang yang percaya kepada-Nya sebagai kawanan domba Allah. Para murid dipercayakan untuk melakukan tugasnya sebagai gembala dan juga akan mencari orangorang tepat yang dapat ditempatkan sebagai gembala yang akan menjaga umat Tuhan.

Orang-orang yang dipercayakan oleh para rasul terus menerus melakukan pengutusan kepada orang-orang yang dipercayakan atas nama Tuhan untuk menjadi gembala atas kawanan domba Allah yang telah dipilih oleh Allah untuk masuk dalam persekutuan-Nya.

\section{Metode Penelitian}

Metodetodologi yang digunakan dalam permasalahan ini adalah difokuskan pada pengamatan dan penelitian kepustakaan (Library Researh)

\section{Pembahasan}

Umat Tuhan akan aman, sehat, bertumbuh, kuat, dan segar bila mendapatkan makanan rohani yang patut baginya. Mereka akan menyaksikan bahwa Tuhan itu benar, adil dan setia kepada umat Tuhan. Dalam keadaan apapun, umat Tuhan akan merasa aman karena memiliki gembala yang peduli dan perhatian. Namun, ketika umat Tuhan dibiarkan, dihindari, diabaikan bahkan dijauhi, mereka akan terhilang dan tidak kembali. Tidak sedikit umat Tuhan yang lupa jalan pulang kepada Gembala Agung. Mereka berjalan sendiri sampai sesat hingga dimangsa oleh ilah-ilah lain. Supaya hal itu tidak terjadi, diperlukan seorang gembala yang memiliki keteladanan dalam hal kasih dan pengorbanan.

\section{A. Peran Gembala Sebagai Pemelihara Umat Tuhan}

Gembala tidak dapat lepas dari peranannya sebagai pemelihara ternak gembalaannya. Gembala bukanlah peranan yang mudah dilakukan sebab menuntut pertanggungjawaban dari Tuhan Pemilik hidup. Dia tidak dapat meninggalkan gembalaannya di padang, lalu pergi berjalan-jalan ke tempat yang jauh dari kawanan domba. Melainkan ia menemani, menuntun dan memperhatikan kebutuhan dombadombanya.

${ }^{1}$ G. R. Beasley-Murray, "Yehezkiel” dalam Tafsiran Alkitab Masa Kini 2 (Ayub-Maleakhi), (Jakarta: YKBK, 2012), 535 


\section{Pengertian Gembala}

Alkitab memberikan dua pengertian tentang gembala, yaitu pertama, orang yang menggembalakan ternak. Kedua, orang yang mengasuh dan membina manusia, yaitu gembala yang bersifat ilahi dan fana. ${ }^{2}$ Demikan juga Kamus Besar Bahasa Indonesia (KBBI), gembala mempunyai 2 (dua) pengertian yaitu pertama, penjaga atau pemiara binatang (ternak); kedua, penjaga keselamatan orang banyak. ${ }^{3}$ Petunjuk Kamus Alkitab, gembala disebut seorang pembimbing dan pemelihara kawanan domba atau kambing. Ia bertanggung jawab atas domba-dombanya, sering menghitungnya dan juga melindunginya terhadap bahaya dari luar. ${ }^{4}$ Sedangkan Kata gembala dalam terjemahan dari bahasa Latin "Pastor" dalam bahasa Yunani "Poimen" yang artinya penjaga. ${ }^{5}$ Dan dalam bahasa Ibrani Kuno, kata gembala ialah "Ra'ah". Kata ini memberikan pengertian yaitu "memberi makan", sehingga gembala disebut sebagai orang yang memberi makan. ${ }^{6}$ Dari penjelasan di atas, dapat dikatakan bahwa gembala dan domba memiliki hubungan yang tidak terpisahkan. Bagaimana supaya domba terawat, terpelihara, dan kelangsungan hidupnya terjamin, gembalalah yang memegang peran penting.

Jadi istilah gembala tidak hanya ditujukan kepada orang yang mengembalakan domba atau ternak yang lain, tetapi gembala juga ditunjukan kepada orang yang memiliki rasa kepedulian kepada orang lain dengan penuh kasih. Tuhan menyamakan umat-Nya dengan domba (Mzm 100:3, Yoh 10:27)

\section{Tugas Gembala}

Peletakan dasar pemula sebelum Yesus naik ke Sorga meninggalkan murid-muridNya, Dia menampakkan diri kepada murid-murid-Nya dan memberikan pengajaran dan nasihat. Nasihat-nasihat itu diberikan setelah mereka makan. Yesus menginginkan murid-murid-Nya yang sudah mulai undur dari panggilannya supaya kembali. Dia menemukan mereka saat sedang menjala ikan. Pekerjaan itu telah dilakukan sebelum Yesus memanggil mereka. Hal ini menunjukkan kemunduran yang dialami oleh para murid.

Sebelum Yesus memberi tugas penting kepada Petrus, Yesus mempertanyakan mengenai kasih Petrus. Dia sepertinya sangat mengingini pernyataan yang tegas dari Petrus mengenai imannya. Pertanyaan yang diberikan Yesus kepada Petrus menimbulkan jawaban yang serius dari Petrus.

Ungkapan "Apakah engkau mengasihi Aku lebih dari mereka ini?" diulang sebanyak tiga kali. Yesus tidak hanya bertanya sekali saja melainkan lebih dari itu. Hal ini menunjukkan bahwa Yesus benar-benar menuntut adanya suatu pernyataan dan jawaban yang serius dari Petrus mengenai kasih-Nya. Herman Bavink menyatakan, "Ia tidak berani lagi membandingkan dirinya dengan murid-murid yang lain. Ia insaf betapa berbahayanya berbuat demikian."7 Petrus tidak lagi melihat dirinya sebagai sesuatu yang melebihi teman-temannya melainkan dia mulai melihat dirinya sebagai pribadi yang tidak lebih dari orang-orang yang ada di sekitarnya.

\footnotetext{
${ }^{2}$ Tim Penyusun, Ensiklopedia Alkitab Masa Kini I, (Bandung: Yayasan Komunikasi Bina Kasih/OMF, 2002), 330

${ }^{3}$ Tim Prima Pena, Kamus Lengkap Bahasa Indonesia, (Gitamedia), 255

${ }^{4}$ Tim Penyusun, Alkitab, (Jakarta: Lembaga Alkitab Indonesia (LAI), 2012), 316

${ }^{5}$ M. Bons-Storm, Apakah Pengembalaan Itu?, 4

${ }^{6}$ Olifer Mc Mahan, Gembala Jemaat Yang Sukses, (Jakarta: BPK Gunung Mulia,1994) 3

${ }^{7}$ J.H. Bavink, Sedjarah Keradjaan Allah Perjajian Baru, (Jakarta: BPK Gunung Mulia, 1951), 397
} 


\section{a. Memberi Makan Domba}

Setelah Yesus mendengar pengakuan Petrus mengenai kasihnya kepada Yesus dan bagaimana respons Petrus terhadap pertanyaan yang diberikan oleh Yesus, maka Dia memberikan perintah kepadanya. Robert Kysar menuliskan, "dalam menanggapi setiap jawaban Petrus, Yesus memerintahkan Petrus untuk memelihara domba-domba-Nya."8 Perintah itu diberikan langsung oleh Yesus. Perintah mengenai orang-orang yang akan menerima dan percaya kepada Yesus baik yang telah percaya saat Yesus berada di dunia maupun setelah Yesus terangkat ke Surga. Orang-orang ini sepertinya dibagi atas kelompok-kelompok. Yohanes 21:15, "gembalakanlah domba-domba-Ku". Pada ayat ini Yesus menggunakan kata $\alpha \rho v i^{9} \alpha^{9}$ untuk menunjuk kepada domba yang akan digembalakan oleh Petrus. Kata ó $\rho v i ́ \alpha$ diartikan anak domba. Guthrie juga memberikan penjelasan yang sama mengenai kata ó $\rho v i ́ \alpha$ (arnia). Bagi Guthrie kata bagian pertama menunjuk kepada anak-anak domba. ${ }^{10}$ Perintah ini diberikan khusus kepada Petrus. Dia dipercayakan untuk menjadi pemimpin atas anak-anak domba yang akan diterima oleh Yesus nantinya. Bavink menuliskan, "Orang yang telah sangat rendah hatinya, sehingga tidak berani lagi membandingkan dirinya dengan orang lain itulah yang dapat Aku pakai untuk memeliharakan domba-domba-Ku."11 Dari penjelasan yang dituliskan oleh Bavink menunjukkan suatu kriteria yang dinginkan oleh Yesus jika ingin menjadi gembala atas anak-anak domba-Nya. Yesus tidak hanya melihat keadaan awalnya melainkan Dia ingin menguji kerendahan hati yang dimiliki oleh seorang yang akan menjadi gembala atas anak domba-Nya.

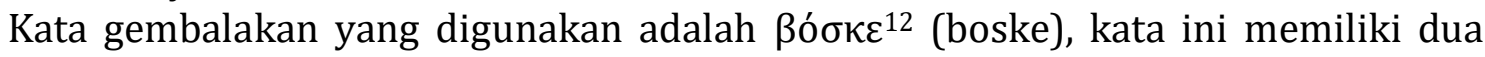
arti yaitu berilah makan dan gembalakanlah. ${ }^{13}$ Penulis lebih memilih kata berilah makan sebab domba yang akan digembalakannya masih sangat kecil sehingga dia masih harus menjaga dan merawatnya dengan benar. Hal yang sama juga diungkapkan oleh Donald Guthrie. Guthrie juga memilih kata berilah makan untuk kata ßó $\sigma \kappa \varepsilon .{ }^{14}$

Tugas pertama yang diberikan kepada Petrus yaitu memelihara anak domba Yesus. Dia tidak langsung dipercayakan kepada domba-domba yang besar melainkan yang kecil terlebih dahulu. Anak-anak domba yang diberikan oleh Yesus pun tidak diberikan batasan melainkan Petrus harus memberi makan semua anak domba yang akan datang kepada Yesus. Matthew Henry mengemukakan bahwa, "Di dalam kawanan domba ini, beberapa di antaranya adalah anak domba, yang masih muda, rapuh dan lemah, dan yang lainnya adalah domba-domba yang sudah tumbuh cukup kuat dan dewasa." 15 Hendry melihat adanya kondisi yang kurang baik untuk melepaskan begitu saja anakanak domba yang telah diberikan.

Kawanan anak domba itu harus dijaga dengan baik bahkan ketika bergerak keluar dari kawanan domba maka sang gembala harus terus memperhatikan agar mereka tidak jatuh karena kondisi fisik mereka yang masih sangat lemah. Mereka masih mudah tersesat dan jatuh karena sangat lemah dan belum mampu mempertahankan diri.

\footnotetext{
${ }^{8}$ Robert Kysar, Injil Yohanes sebagai Cerita (Jakarta: BPK Gunung Mulia, 1995), 97

${ }^{9} \dot{\alpha} \rho v i ́ \alpha$ merupakan kata benda akusatif neuter jamak yang menunjukkan umum yang berarti anak domba

${ }^{10}$ Donald Guthrie, 'Yohanes' dalam Tafsiran Alkitab Masa Kini III (Matius-Wahyu), W. B. Sijabat (penerjemah) (Jakarta: Yayasan Komunikasi Bina Kasih, 1994), 330

${ }^{11}$ Bavink, Sedjarah Keradjaan Allah Perjajian Baru, 397

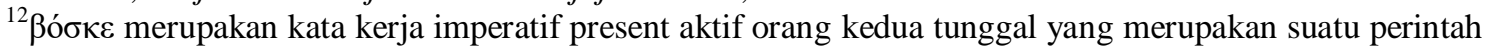
berilah makan atau gembalakanlah.

${ }^{13}$ Pencarian di Bibleword

${ }^{14}$ Guthrie, 'Yohanes' dalam Tafsiran Alkitab Masa Kini III (Matius-Wahyu), 330

${ }^{15}$ Matthew Henry, Injil Yohanes 12-21, (Surabaya: Momentum, 2010), 1454
} 
Menurut Henry, "Sekalipun sudah ada kawanan yang dewasa dan cukup kuat tetapi Tuhan Yesus tetap menyerahkan anak-anak domba kepada Petrus supaya dipelihara dan tetap memberikan makan kepada mereka sesuai dengan makanan yang cocok buat mereka." 16

Kata 'anak domba' dalam kehidupan orang percaya tidak selamanya menunjuk kepada kondisi fisik. Kata seorang 'anak-anak' dari status iman juga dapat ditujukan kepada seorang yang baru percaya kepada Kristus. Mereka seorang yang masih lemah, buta, dan mudah sesat atau dipengaruhi oleh lingkungannya. Yesus menginginkan agar orang yang menjadi pemimpin atas mereka adalah orang-orang yang benar-benar mengasihi Dia. Henry menuliskan, "Kristus sedemikian memperhatikan umat-Nya sehingga Dia tidak akan mempercayakan mereka kepada siapa pun kecuali kepada orang yang mengasihi Dia."17 Yesus tidak mau mempercayakan orang-orang yang baru percaya kepada-Nya. Dia sangat menginginkan ada orang yang benar-benar mengasihi Dia yang akan menggembalakan anak-anak domba-Nya. Seorang tidak mungkin mengasihi domba gembalaannya jika dia tidak mengasihi tuan pemilik domba tersebut.

Orang yang baru percaya mudah diombang-ambingkan oleh berbagai pengajaran. Dia belum teguh dalam imannya sehingga dibutuhkan seorang yang benar-benar mengasihi dan mengenal Allah dengan sepenuh hidupnya. Seorang gembala perlu mengetahui apa yang dibutuhkan oleh anak domba. Dia tidak dapat dengan sembarangan memberikan makanan yang tidak sesuai dengan kemampuan anak-anak domba tersebut.

Penugasan Petrus tidak berhenti pada anak-anak domba. Pengakuan kedua dari Petrus ditanggapi Yesus dengan pernyataan yang lebih besar lagi. Yesus tidak lagi memberikan anak domba melainkan kelompok domba yang lebih besar lagi. Kata yang dipakai Yesus untuk menunjuk kepada domba, perintah kedua-Nya berbeda dengan yang pertama. Kata $\pi \rho o ́ \beta \alpha \tau^{\prime 18}$ (probata) yang berarti domba-domba. Kata ini tidak lagi menunjuk kepada domba-domba yang lemah karena masih kecil tetapi domba-domba yang sudah besar namun tetap membutuhkan seorang gembala untuk menuntun mereka agar tetap berada dalam jalan yang Tuhan tunjukkan.

Kata $\pi \rho o ́ \beta \alpha \tau \alpha ́$ lebih mencakup kepada semua domba yang telah besar sehingga sekalipun tubuhnya sudah bertumbuh dan dapat berjalan sendiri namun Yesus masih menginginkan Petrus menggembalakan mereka. Guthrie juga memberikan pendapat yang sama mengenai arti yang terkandung di dalamnya yaitu domba-domba. ${ }^{19}$ Yesus tidak lagi memberikan batasan khusus kepada Petrus dipernyataan keduanya. Yesus sudah berani memberikan domba yang lebih besar lagi kepadanya. Bruce Milne berpendapat bahwa perbedaan antara"anak-anak domba" dan "domba-domba" mungkin mempunyai makna tertentu, tetapi sangat sulit untuk melihat perbedaan ini dalam katakata lainnya. ${ }^{20}$ Bagi Milne kedua bahasa yang digunakan tidak mudah untuk menentukan maksud tertentu yang Yesus ingin sampaikan. Namun berbeda dengan Bavink. Bagi Bavink, Yesus mempercayakan kepada Petrus bukan saja anak-anak domba, tetapi segala domba dan Petrus bukan saja memeliharanya (mencarikan makanan), tetapi betul-betul menjadi gembala yang benar. ${ }^{21}$ Bavink lebih berani memberikan perbedaan yang mendasar di antara kedua kata yang dipakai oleh Yesus saat menanggapi pernyataan Petrus. Bagi Bavink, tugas kedua benar-benar menuntut Petrus untuk menjadi seorang gembala yang sungguh-sungguh bukan hanya mengenal

\footnotetext{
${ }^{16}$ Henry, Injil Yohanes 12-21, 1454

${ }^{17}$ Henry, Injil Yohanes 12-21

${ }^{18} \pi \rho o ́ \beta \alpha \tau \alpha ́$ merupakan kata benda akusatif neuter jamak yang bersifat umum yang berarti domba-domba

${ }^{19}$ Guthrie, "Yohanes", 330

${ }^{20}$ Bruce Milne, Yohanes (Lihatlah Rajamu), (Jakarta:Yayasan Komunikasi Bina Kasih, 2010), 480

${ }^{21}$ Bavink, Sedjarah Keradjaan Allah Perjajian Baru , 397
} 
dan memberi makan melainkan dia harus melakukan tugas yang lebih lagi terhadap domba-domba baik yang kecil maupun yang dewasa.

Kata yang dipakai oleh Yesus untuk memerintahkan Petrus mengenai tugas

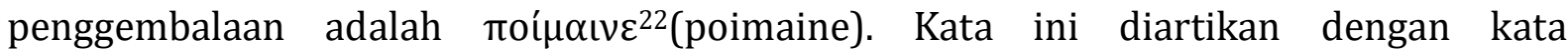
menggembalakan. Guthrie mendefinisikannya dengan pelihara. ${ }^{23}$ Definisi Guthrie menunjukkan tugas Petrus yang berbeda dengan yang pertama. Dia ditugaskan untuk memelihara. Dalam pekerjaan memelihara dia juga harus mengetahui apakah peliharaannya sudah makan atau belum dan bagaimana gerak setiap domba. Dia tidak hanya mengantarkan domba-domba ke padang untuk menggembalakannya melainkan dia juga harus dengan sabar menemani mereka sampai mereka kenyang dan beristirahat.

Petrus tidak hanya ditugaskan untuk menempatkan mereka di padang supaya mereka dapat makan melainkan dia harus benar-benar harus menjadi penjaga dan penuntun.

Henry melihat lebih jauh lagi. Bagi dia, Kata yang digunakan dalam ayat 16 adalah тоí $\mu \alpha \nu \varepsilon$, yang jauh lebih menyatakan tindakan mengerjakan semua tugas seorang gembala bagi mereka: "berilah anak-anak domba makanan yang cocok. Carilah dan beri makan domba-domba lain, yang bukan dari kandang ini." ${ }^{24}$ Penjelasan Henry menunjukkan adanya tugas baru yang diberikan Yesus kepada Petrus yaitu memberikan makan kepada domba-domba lain yang berasal dari luar kandang. Dia tidak boleh membeda-bedakan domba melainkan dia harus benar-benar menjadi gembala yang membuat domba yang berasal dari luar merasa nyaman saat berada di dalam kumpulan domba milik Yesus. Kenyamanan itu tidak dapat diberikan Petrus dengan sendirinya melainkan dia harus benar-benar mengetahui apa yang Tuhan mau sehingga dombadomba-Nya dapat bertahan sekalipun baru masuk dalam kumpulan tersebut.

Respons ketiga dari Petrus adalah menyatakan kasih sekaligus dia bersedih atas pertanyaan yang tiga kali dilontarkan oleh Yesus. Pernyataan yang begitu rendah yang disampaikan oleh Petrus membawanya pada penghayatan bahwa kasih pada dirinya tidak cukup untuk menyatakan kasihnya kepada Yesus.

Setelah Yesus mendengar pernyataan Petrus, Dia meresponsnya dengan memberikan perintah yang ketiga yaitu berilah makan domba-dombaku. Yesus kembali

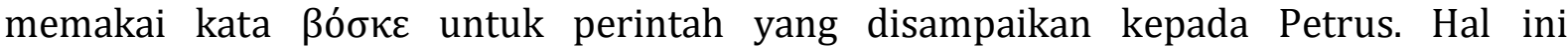
menunjukkan keinginan yang besar dari Yesus agar orang yang diberikan tanggung jawab tidak hanya menjaga dan menuntun para domba melainkan harus memberi makan agar mereka tetap sehat. Henry menyatakan,

Tuhan Yesus ingin agar Petrus benar-benar memelihara domba-domba-Nya. Jangan hanya mengumpulkan dan dan menjaga tetapi Petrus harus mengetahui kondisi kesehatan setiap domba dan makanan bagi setiap tingkatan dari domba. Gembalakanlah mereka secara pribadi sesuai dengan keadaan dan masalah mereka masing-masing. Bukan sekadar meletakkan makanan di hadapan mereka, tetapi menyuapi mereka dengan makanan tersebut, baik mereka yang mau maupun yang tidak mau, atau yang lemah dan tidak dapat makan sendiri.25

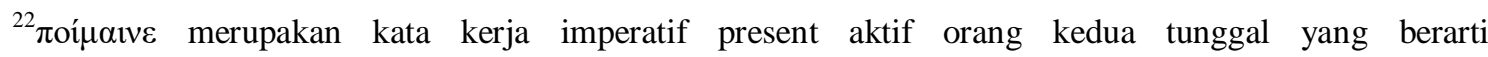
menggembalakan.

${ }^{23}$ Guthrie, 330

${ }^{24}$ Henry, Injil Yohanes 12-21, 1454

${ }^{25}$ Henry,Injil Yohanes 12-21, 1454
} 
Berdasarkan pernyataan Henry terlihat suatu keinginan besar dari Yesus terhadap keseriusan dari gembala yang dipilih-Nya. Petrus tidak hanya diperintahkan untuk merawat, menuntun, memasukkan ke kandang, namun Petrus harus merawat mereka saat sakit, menjamin keamanan mereka, dan memberikan makanan yang dibutuhkan. Henry sampai memberikan penekanan bahwa gembala harus menyuapkan makanan yang dibutuhkan agar domba tersebut dapat makan.

Seorang yang menyandang diri sebagai seorang gembala, kepadanya diberi tugas untuk menggembalakan domba ke padang yang berumput hijau. Gembala memiliki tujuan yang pasti supaya jemaat yang dilayani mengalami kuasa Tuhan dalam dirinya. Inilah yang dinamakan bertumbuh.

\section{b. Melindungi Domba dari Binatang buas}

Domba menyukai jalan sendiri. Akibatnya menyebabkan celaka karena terkaman binatang buas. Di sinilah diperlukan tugas gembala yakni melindungi domba tersebut. Seperti halnya pengajaran dan tawaran dunia kepada umat Tuhan yang menyebabkan mereka terpengaruh dan meninggalkan Tuhan. Melalui penggembalaan, gembala dapat memproteksi keberadaan dombanya. Gembala dapat menyaksikan domba-dombanya sehat dan segar. Baik secara jasmani, maupun rohani. Menurut J.W Herfst bahwa penggembalaan itu ialah menolong setiap orang untuk menyadari hubungan-Nya dengan Allah, dan mengajar orang untuk mengakui ketaatannya kepada Allah dan sesamanya." 26 Domba dikenal sebagai hewan peliharaan yang lemah dan mudah sesat. Itulah sebabnya perlu digembalakan seorang gembala yang ditetapkan Tuhan. Di sini seorang gembala akan berjuang menjaga kawanan domba dari segala hal yang mengancam mereka.

Bons-Strom mengatakan bahwa seorang gembala yang baik adalah seorang yang bekerja sampai lelah. Ia harus waspada dan berani, bahkan bersedia mempertaruhkan nyawanya sendiri untuk domba-nya." ${ }^{27}$ Maksudnya menjadi gembala harus berani mempertaruhkan nyawanya demi keselamatan domba-domba-nya. Peter Wongso menambahkan bahwa: seorang hamba Tuhan harus berkorban bagi Tuhan dan jemaat nya tanpa pamrih maka upahnya besar di surga (Mat 6:33). Akan tetapi sekali-kali janganlah baru mau berkorban karna ada pahala yang di surga." 28 Berkorban tanpa memikirkan keselamatan diri sendiri adalah ciri khas dari seorang gembala hal ini tidak hal yang mudah untuk dilakukan. Karena kerapkali gembala beranggapan berkorban bagi jemaat cukup pada hari Minggu, tidak memperhatikan jemaat dalam hal lainnya, misalnya dalam keadaan sakit, tidak aktif dalam mengikuti ibadah. Gembala yang melayani hanya untuk mencari nafkah atau kehormatan termasuk orang upahan Yohanes 10:12-13."29 Fakta membuktikan masih ada gembala yang belum memahami secara benar perannya sebaga wakil Tuhan. Hal ini menjelaskan bahwa di lapangan ditemukan gembala-gembala yang tidak serius melayani, mengakibatkan domba tercerai-berai.

Allah menghendaki seorang gembala yang baik bagi domba-domba-Nya. Robert Kysar mengatakan bahwa, Yesus adalah "gembala yang baik", sehingga dibandingkan dengan yang lain (orang-orang upahan) yang tidak memiliki domba-domba dan tidak melindungi mereka." ${ }^{30}$ Mereka telah berlaku tidak setia kepada Allah. Itulah sebabnya Allah tegas mempertegas akan tugas dan tanggung jawab seorang gembala.

\footnotetext{
${ }^{26}$ M, Bons-Strom, Apakah Penggembalaan Itu ( jakarta: BPK Gunung Mulia, 2009 )1.

${ }^{27}$ Bons Strom, apakah Penggembalaan itu ( jakarta: BPK Gunung Mulia, 2009 )3.

${ }^{28}$ Peter Wongso, Teologia Penggembalaan ( Malang: literatur SAAT, 2007 )21.

${ }^{29}$ www. Golgothaministri.orang /yohanes.

${ }^{30}$ RoberthKysar, InjilYohanes( Jakarta: BPK GunungMulia 1995 ). 46
} 


\section{c. Menumbuhkan Iman Jemaat}

Ketika jemaat bertumbuh dan dekat kepada Tuhan serta mengasih Dia, seorang hamba Tuhan akan bahagia. Bagaimana seorang gembala untuk melakukan bimbingan, pengajaran, motivasi dan menuntun jemaatnya guna mencapai tingkat kedewasaan. Namun, pencapaian itu tidak akan terlaksana tanpa ada komunikasi dan keakraban antara gembala dan jemaatnya. Sebagaiaman yang dikemukakan oleh E. Igouf bahwa, pergaulan yang baik antara gembala atau pendeta dengan jemaatnya, tergantung pada kasih dan kepercayaan, kedua sifat ini tidak akan terjadi dengan otomatis, tetapi harus dikembangkan". ${ }^{31}$ Di sini dibutuhkan saling percaya dan ada keterbukaan antara gembala dan jemaat. Keterbukaan itu diartikan dalam hal pelayanan. Gembala mengasihi jemaat dan sebaliknya jemaat menghormati dan mengasihi. Di sini tercipta saling menghargai sebagai umat Tuhan di dunia ini. Selanjutnya Edgar Walz menyatakan bahwa,

Sebagai pendeta (gembala), ia menjalankan peran sebagai pemimpin rohani ketika bekerja sama dengan orang-orang lain dalam pelayanaan. Ia menjadi pembimbing dan pelatih bagi orang yang membantunya. Peran pendeta di sini menjadi berbeda dengan peran manejemennya dalam 'menjalankan' gereja. Dalam peran pastoral ia membimbing 'sukarelawan' yang bekerja dengannya. Pada saat yang sama sukarelawan ini juga berpartisipasi sebagai teman seiman dalam gereja Kristus. Tentu saja, fungsi pengawasan pastoral ini merupakan kombinasi antara kepemimpinan rohani dan manajerial. Keseimbangan antara satu dengan yang lainnya tergantung pada minat serta kemampuan si pendeta maupun minat dan kemampuan orang-orang yang bekerja sama dengannya. ${ }^{32}$

Artinya seorang gembala dapat menempatkan dirinya sebagai pemimpin. Dimana seorang pemimpin memahami akan tanggungjawabnya di dalam jemaat.

\section{d. Memperhatikan kebutuhan Jemaat yang baru bertobat}

Jemaat yang baru bertobat akan merasakan suasana yang asing di perkumpulan orang Kristen. Dalam rasa asing ini, gembala perlu memberi perhatian khusus dan istimewa kepadanya supaya ia merasa diterima dan dikasihi. Ralps M. Riggs sebagai berikut: Tugas lain yang dibebankan kepada seorang gembala adalah "memelihara" gereja dalam pendamaian, kasih, dan persatuan (Yak.3:16). Supaya mereka saling mengasihi sebagaimana doa Yesus (Yoh. 13:34). Melayani dengan kasih (Gal. 5:22; I Kor. $12: 13$; 13:2). Dikatakan pekerjaan seorang pendeta atau gembala membawa orangorang saleh kepada kedewasaan penuh (Ef. 4:13), dan tujuan Paulus sebagaimana yang dikatakan Kolose 1:28, yakni berusaha dengan segala tenaga untuk memimpin tiap-tiap orang pada kesempurnaan dalam Kristus Yesus. ${ }^{33}$ Sebagai seorang gembala harus melindungi dombanya dari berbagai ancaman yang akan membahayakan dombanya sendiri. Dalam pekerjaan ini Ia juga subjek dan dipakai-Nya sebagai alat-Nya. Ia bukan saja datang untuk mencari yang sesat dan hilang dan menghimpunkan yang tercerai-

\footnotetext{
${ }^{31}$ John E. Igouf, dalam bukunya dikutip oleh, Karel Sosipater, Etika Pelayanan (Jakarta: Suara Harapan Bangsa, 2009), 63

${ }^{32}$ Edgar Walz, Bagaimana mengelolah gereja anda ( Jakarta: BPK Gunung Mulia2011), 8

${ }^{33}$ Ralps M. Riggs, Gembala Sidang Yang Berhasil, (Jakarta: Gandum Mas.2003)
} 
barai, tetapi juga untuk "melindungi" mereka dari rupa-rupa bahaya, rohani, dan jasmani. ${ }^{34}$

\section{e. Mengenali kebutuhan Jemaat yang baru Bertobat}

Demikian juga halnya para pemimpin Israel pada zaman nabi-nabi. Yehezkiel 34:4 berkata, yang lemah tidak kamu kuatkan, yang sakit tidak kamu obati, yang luka tidak kamu balut, yang tersesat tidak kamu bawa pulang, yang hilang tidak kamu cari, melainkan kamu injak-injak mereka dengan kekerasan dan kekejaman." ${ }^{55}$ Warren W. Wiersbe menjelaskan berbahagialah domba Allah yang mempunyai gembala yang dapat mengarahkan dan memimpin ke jalan yang sesuai dengan kehendak Tuhan. ${ }^{36}$ Domba adalah binatang yang perlu bimbingan dari gembalanya, karena kehidupan domba bergantung kepada gembalanya. Meskipun domba bertumbuh di negara yang kering dan semi-gersang, mereka tetap membutuhkan air. ${ }^{37}$ Domba-domba adalah binatang yang aneh, jinak, tidak mampu melawan. Pada kenyataanya, mereka itu bodoh. Mereka tidak tahu arah tujuan hidupnya, mereka tidak tahu apa yang terbaik bagi mereka, dan mereka berjalan kemana-mana dengan tidak sadar, menjerumuskan diri mereka sendiri ke dalam keadaan yang berbahaya. ${ }^{38}$ David Farel Sibuea dalam bukunya menyatakan citra dan misi penggembalaan adalah "Gembala dan kawanannya harus menggembara antara gurun dan lembah, berpindah dari padang gurun pada musim semi, hujan, tandus dan panas, lembah-lembah, memberi air pada musim panas dan menghadapi binatang buas dan pencuri, tetap bertanggung jawab untuk memelihara, takkan kekurangan, membaringkan di padang gurun rumput, membimbing dan menuntun domba, menyegarkan, menuntun ke jalan yang benar dan selalu bersama-sama dengan dombanya kapan dan dimana saja ada kesulitan yang dialami domba". ${ }^{39}$ Seorang pendeta (gembala) adalah seorang dokter rohani, dan merupakan pembimbing, yang dalam pelayanannya harus mengetahui kebutuhan anggota jemaatnya. ${ }^{40}$

Di dalam 1 dan 2 Timotius dijelakan bahwa Gembala juga harus tahu apa yang dibutuhkan oleh jemaatnya. Seperti kasih, pengakuan, doa, persahabatan, pengertian, simpati, dan nasihat. Dan yang terpenting di sini adalah gembala harus melakukan perkunjungan pribadi ke rumah jemaat sebagai bentuk perhatian khusus kepada jemaatnya. Tujuannya ialah mendewasakan iman dan bukti pertumbuhan rohani mereka. Dengan melakukan demikian mereka merasakan bahwa lawatan Tuhan selalu hadir bersama-sama dengan mereka, sehingga hari lepas hari mereka tetap mempertahankan iman kepada Yesus. Gembala memiliki pelayanan dalam memberi makan, memelihara dan mendewasakan anggota kawanan dombanya.

\section{f. Mengajarkan Firman Tuhan kepada orang yang Baru Percaya Kepada Yesus}

Firman Tuhan berkuasa untuk menyembuhkan, memberi petunjuk, melawat dan meneduhkan. Orang yang baru percaya membutuhkan tuntunan sebagaimana menuntun anak kecil. Ia dibela, disanjung dan dipuja supaya mereka merasa nyaman dan dihargai. Gembala dituntut oleh Tuhan menjaga yang terkecil (Mat. 18:2-6, 11).

\footnotetext{
${ }^{34}$ J.L. Ch. Abineno, pengembalaan (Jakarta: BPK Gunung Mulia, 1967) 38

${ }^{35}$ Dave Hegelberg, Tafsiran Injil Yohanes pasal 6-12, ( Yokyakatra: Andi, 2009 ). 141

${ }^{36}$ Warren W. Wiersbe, Prioritas Seorang Gembala. (Malang: Gandum Mas, 1982).59

37 W. Phillip Keller,A Sherperd Looks At Psalm 23,(Jakarta: PT Abiyah Pratama, 2008) 65

${ }^{38}$ Richard L. Strauss, Bagaimana Memahami Kehendak Tuhan, 25

${ }^{39}$ David Farel Sibuea, Citra dan Misi Penggembalaan, (Jakarta: T.N.P 2004) 89

${ }^{40}$ Peter Wongso, Theologia Penggembalaan, 112
} 
"Yang tekecil" yang dimaksud tidak hanya mengacu kepada anak-anak kecil, tetapi juga kepada petobat-petobat baru di dalam Kristus. ${ }^{41}$ Dalam hal ini gembala perlu mengarahkan perhatian bagi petobat-petobat baru. Mereka yang masih baru bergabung perlu diberi perhatian khusus supaya merasa diperlakukan dengan baik. Thurnesysen menyatakan bahwa, penggembalaan merupakan suatu penerapan khusus injil kepada anggota jemaat secara pribadi, yaitu berita injil yang dalam khotbah gereja disampaikan kepada semua orang. ${ }^{42}$ Sedangkan J. W. Herfst menyatakan bahwa, tugas penggembalaan ialah menolong setiap orang untuk menyadari hubungannya dengan Allah, dan mengajar orang untuk mengakui ketaatannya kepada Allah dan sesamanya, dalam situasi sendiri.43 Pelayanan kepada orang baru bertobat harus secara terus menerus dan berkelanjutan bukan di hari raya musiman. Contohnya: hari Paskah, Kenaikan Tuhan Yesus ke Sorga, dan Natal. Karena bila hal ini terjadi akan menyebabkan jemaat tersebut kehilangan perhatian dari seorang gembala. Jikalau kebiasaaan ini tidak diubah oleh seorang gembala akan menyebabkan kehilangan kepercayaan terhadap gembala.

\section{g. Membimbing Jemaat yang Telah Dewasa Iman}

Pelayanan meliputi semua usia. Baik yang sudah lama menjadi orang Kristen ataupun yang baru bertobat. Tujuan akhir dari pertumbuhan jasmani dan rohani jemaat ialah kemuliaan Tuhan dinyatakan dalam hidup mereka. Jemaat Tuhan dapat bertumbuh karena mendengar suara gembalanya, bila gembalanya telah mengalami keintiman secara rohani dengan jemaat binaannya. Sebagaimana yang Yesus katakan bahwa, "Domba-domba-Ku mengenal suara-Ku"(Yoh. 10:27).44 Oleh karena itu, gembala perlu menempatkan integritas diri sebagai gaya hidup. Artinya seorang pemimpin yang baik diwujudkan melalui sikap hidup, kerohanian, imannya, dan moralitasnya. Dengan demikian, pemimpin tersebut dipandang layak menjadi seorang gembala yang baik.

Gembala dapat dikenal oleh jemaatnya karena gembala tersebut selalu rutin memelihara dan melindungi jemaatnya serta membuat jadwal untuk mengunjungi mereka ke rumahnya. Gembala yang baik adalah gembala yang mencintai semua kawanan dombanya dan tidak pandang bulu, satu domba tidak terlihat semua dicarinya, domba yang sakit dirawatnya, dan gembala berjalan di depanya. Hal ini dilakukan oleh seorang gembala, mengingat selalu ada ancaman atau musuh yang akan mencelakai domba tersebut. Contohnya munculnya ajaran sesat yang memutar balikkan kebenaran. Hal ini dilakukan untuk kepentingan pribadi. Untuk itu gembala harus lebih dulu menghadapinya dan melindungi domba-dombanya. ${ }^{45}$ Kesiapan seorang gembala menjadi tokoh yang ditiru dan dipatuhi oleh jemaat. Injil Yohanes 21:15-19 menjelaskan bahwa, Petrus perlu memelihara domba-domba-Nya yang dipercayakan kepadanya.

Yesus sendiri mengibaratkan atau menyamakan pelayanan kepada saudarasaudara kita dalam Diri-Nya itu, dengan "pengembalaan". Jadi saudara-saudara itu hendaknya dijaga, dipelihara, dibimbing dan diselamatkan dari bahaya. ${ }^{46}$ Pelayanan yang serius dari seorang gembala menyebabkan jemaat menikmati suasana sorga atas dirinya. Dengan demikian, gembala mempunyai peran yang sangat penting dalam

\footnotetext{
${ }^{41}$ www. Peran Gembala. com

42 Thurnesysen, didalam bukunya yang dikutip oleh M. Bons-Strom, Apakah Penggembalaan Itu, 1

${ }^{43}$ Thurnesysen, didalam bukunya yang dikutip oleh M. Bons-Strom, Apakah Penggembalaan Itu, 1

44 Sosipster, Etika pelayanan 63

${ }^{45}$ Sosipster, Etika pelayanan 65

${ }^{46}$ M. Bons-Storm, Apakah Pengembalaan Itu? ( Jakarta: Bpk Gunung Mulia, 2009), 3-4
} 
mengembalakan jemaat yang dipimpinnya, karena penggembalaan merupakan bagian utama dari pelayanan gereja.

Domba atau jemaat tidak terlepas dari persolan hidup karena sejak manusia jatuh dalam dosa, segala yang baik sering dipeleseti oleh kedagingan manusia. Itulah sebabnya kehadiran gembala sangat diharapkan untuk menolong jemaat yang sedang menghadapi kesulitan dan mengangkat mereka dari keterpurukan tersebut serta memperkenalkan kuasa Tuhan yang sanggup memulihkan.

Gembala tidak menjaga teladan dan integritasnya sendiri sebagai orang yang telah dipanggil untuk melayani dan menjaga kawananan dombanya. Sehingga di mata jemaat, gembala sama saja dengan kaum awam. Dengan teladan dan integritas seorang gembala dapat mencerminkan kehidupan gembala itu sendiri, sebagai orang yang benar-benar dipilih dan dipanggil untuk melayani jemaat Tuhan.

Gembala tidak menguasai dirinya, sehingga tidak jarang gembala bertengkar dengan pengurus gereja dan jemaatnya, sehingga nama baik gembala tercoreng di mata jemaatnya sendiri. Ini disebabkan karena gembala cepat emosi, tidak sabar, dan kadang tidak mau menerima pendapat atau masukan dari jemaatnya. Padahal dengan banyaknya masukan atau pendapat dari pengurus dan jemaat, dapat membuat gereja itu sendiri bertumbuh dan berkembang dengan baik. Akibat dari semua itu, jemaat pindah ke gereja lain dan ada juga diantara mereka tidak mau lagi beribadah karena mereka merasa kecewa dengan gembalanya sendiri. Padahal seharusnya gembala merangkul, membimbing, membina, dan menasehati jemaatnya, supaya kerohanian jemaatnya dapat ditingkatkan dengan baik.

\section{h. Merangkul Semua Jemaat}

Melayani jemaat secara adil dan benar adalah kesukaan bagi Tuhan. Sebagai pelayan firman yang terpanggil dan sudah didik secara teologis, pendeta (gembala) melakukan banyak tugas yakni memberitakan Firman Tuhan dan fungsi-fungsi pastoral. Fungsi-fungsi ini sudah termasuk memimpin kebaktian, berkhotbah, melayani sakramen, melayani kelompok dan individu-individu serta mewakili jemaat untuk gereja dan dunia. ${ }^{47}$ Jadi orang yang memberitakan Firman selalu harus mempertimbangkan apakah beritanya itu dapat membentuk jemaat, apakah dapat menjadikan hidup mereka bertumbuh. ${ }^{48}$ Pertumbuhan tersebut dilakukan dengan cara mengunjungi jemaat satu persatu. Karena melalui perkunjungan, jemaat akan merasa diperhatikan dan diperdulikan.

Menurut Peter Wongso bahwa, tujuan melakukan pekerjaan perkunjungan seorang pendeta/gembala adalah pertama, mempererat persahabatan, kedua, Memperdalam perkenalan secara langsung, ketiga Mengetahui keadaan yang sesungguhnya, mengenai keadaan dan kebutuhans rohani dan jasmani setiap jemaat, keempat Mempunyai bahan-bahan dan kesemapatan untuk membantu seperti, dapat membentunya melalui mediators dan dapat membentunya melalui khotbah. ${ }^{49}$ Sedangkan Robert G. Witty menyatakan bahwa, biasanya ada tiga macam tujuan kunjungan yaitu, Pertama kunjungan untuk meningkatkan jumlah hadirin di gereja. Kedua kunjungan penginjilan. Tujuan kunjungan semacam ini ialah menjelaskan injil dan cara keselamatan kepada orang yang dikunjungi. Ketiga kunjungan untuk keperluan khusus. Keperluan untuk orang Kristen baru ialah metode kehidupan dan asas

\footnotetext{
${ }^{47}$ Edgar Walz, Bagaimana Mengelola Gereja Anda, 7

${ }^{48}$ Peter Wongso, Theologia Penggembalaan, 20

${ }^{49}$ Peter Wongso, Theologia Penggembalaan, (Malang: Literatur SAAT, 2011) 103
} 
kepercayaan Kristen. ${ }^{50}$ Melalui perkunjungan, gembala dapat bersama dengan jemaat mengalami pertumbuhan.

Rick Warren mengatakan bahwa pertumbuhan kualitas menunjuk pada jenis-jenis murid yang dihasilkan oleh gereja. Apakah ia benar-benar berubah menjadi seperti Kristus, hidup dalam kebenaran firman Allah dan bersaksi sebagai bentuk pelayan penginjilan. ${ }^{51}$ Menurut Saparman ciri-ciri orang yang bertumbuh kerohaniannya adalah membuang dosa, merindukan firman Allah, menikmati kebaikan Allah. ${ }^{52}$ Orang Kristen hidup oleh iman, tanpa iman kekristenannya menjadi tidak berarti dan tidak berkenan kepada Allah. Ibrani 10:35-39 berkata "sebab itu janganlah kamu melepaskan kepercayaanmu, karena upah yang menantinya, sebab kamu memerlukan ketekunan, supaya sesudah kamu melakukan kehendak Allah kamu memperoleh apa yang dijanjikan itu". ${ }^{3}$ Dalam bukunya, Frederick K.C. Price menyatakan bahwa, seseorang dapat bertumbuh imannya apabila orang itu memiliki dan mengetahui firman Tuhan, inilah kunci pertumbuhan iman orang percaya yakni tidak sekedar memiliki kebenaran tapi mengetahui kebenaran, karena itu firman Tuhan harus mendapat tempat yang paling utama dalam hidup orang percaya. ${ }^{54}$ Sejak firman itu ditabur hingga menghasilkan buah ratusan kali lipat, sudah pasti diperlukan banyak perhatian untuk pemeliharaan dan pertumbuhan firman di dalam hidup kita. ${ }^{55}$ Derek Prime menyatakan, "Iman adalah tindakan yang menentukan, sikap terus-menerus, iman sebagai tindakan seseorang yang membuang kepercayaan pada diri-sendiri untuk mendapatkan keselamatan"56 Sedangkan John R. Tan menyatakan, "sumber dari iman yang sejati adalah berasal dari Allah. Artinya jadi pengikut Tuhan dan beriman kepada-Nya adalah merupakan anugerah Tuhan dan manusia yang mengambil keputusan kepada siapa dia beriman." 57 Eddy Leo menyatakan, iman seseorang adalah hidup kudus dalam kebenaran Tuhan, iman adalah pendorong untuk melakukan perbuatan-perbuatan baik kepada Tuhan yang dilakukan oleh kekuatan manusia. Jadi iman yang menyelamatkan adalah iman yang percaya bahwa Yesus adalah juruselamat dan sekaligus Tuhan yang ditaati. ${ }^{58}$ Gembala harus bergaul akrab dengan kawanan dombanya. Tidak boleh ada sesuatu yang membuat mereka terpisah, baik satatus sosial, pendidikan, usia, dan lain sebagainya. ${ }^{59}$ Mengikuti dan mengasihi Yesus berarti menerima tanggung jawab terhadap terhadap umat Yesus. ${ }^{60}$

\section{Gembala Masa Kini}

Ada dua macam gembala menurut Alkitab, yakni gembala yang baik dan tidak baik. Seorang Gembala yang baik pasti mengenal domba-dombanya, mengetahui kondisi jemaatnya, mengenal nama-nama domba-dombanya, serta memberi nama sesuai dengan sifat masing-masing (Yoh. 10:3,14). Seorang Gembala juga harus memberikan makanan kepada domba-dombanya. Makanan yang diberikan adalah makanan dari

\footnotetext{
${ }^{50}$ John E. Inggouf, Sekelumit Tentang Gembala Sidang, (Bandung: Lembaga Literatur Baptis, 1988) 61

${ }^{51}$ Rick Warren, The Purpose Driven Church, (Malang: Gandum Mas, ) 56

52 Saparman, Menjadi Dewasa Secara Rohani, (Bandung: Kalam Hidup, 1997) 200

${ }^{53}$ David O. Oyedepo, Eksplotasi iman, (Jakarta: Metanoi, 2008) 2

${ }_{55}^{54}$ Friderick K.C. price, Saran-Saran Praktis untuk Pelayanan yang Berhasil (Jakarta: Imanuel, 1993) 25

55 Billy Joe Daugherty, Kuasa Iman, (Bandung: Kalam Hidup, 2004) 63

${ }^{56}$ Derek Prime, Alkitab Menjawab Pertanyaan Tentang Iman Kristen, (Jakarta: Yayasan Bina Kemusih, 1995) 84

57 John R. Tan, Dinamika Pertumbuhan Kristen, (Jakarta: Yasinta, 2006)12

${ }^{58}$ Eddy Leo, Iman Seutuhnya, (Jakarta: Gunung Sahari, 2005) 4

${ }^{59}$ Stephen Tong, Hidup Kristen Yang Berbuah, (Surabaya: Momentum, 2008) 10

${ }^{60}$ Bruce Milne, Seri Pemahaman Dan Penerapan Amanat Alkitab Masa Kini Yohanes, (Jakarta: Yayasan Komunikasi Bina Kasih, 2010 ) 484
} 
firman kebenara. Jadi seorang Gembala yang sedang memberikan firman harus selalu mempertimbangkan apakah beritanya itu dapat membantu jemaatnya, apakah dapat menjadikan hidup hidup mereka bertumbuh.

Seorang Gembala harus menggembalakan domba-dombanya di padang rumput yang hijau (Yeh. 34:14). Penggembalaan berakar dalam gambaran akan Allah sebagai gembala umat-nya."61 Sebagai gembala ia mendengar, membimbing, menyertai, menghibur, dan mengumpulkan kawanan dommba-Nya ( Kej. 49:24; Mzm. 23:1-6; Yeh. 34:11-31). Allah adalah gembala yang menuntun, membimbing, mengasihi, memelihara, dan melindungi domba-domba-Nya.

Seorang gembala yang baik harus memanggil domba-domba yang telah hilang, supaya kembali. Gembala adalah seorang'penyelamat', ia harus mengelamatkan dombadomba yang karena kebodohannya, dan bila mana seorang anggota jemaat yang tersesat, maka ia sedang melakukan pekerjaan gembala. Oleh karena itu gembala yang baik harus menanamkan jemaatnya semangat dan keharusan mengikut Tuhan. Di dalam mengikut Tuhan dan melayani Tuhan, sangatlah dibutuhkan kesetiaan dan rasa tanggung jawab yang besar. Panggilan Tuhan bagi setiap orang untuk melayani Dia dan sesama adalah panggilan untuk menjadi seorang hamba ( pelayan), dan apa yang diharapkan dari seorang gembala atau hamba Tuhan yang diberi kepercayaan oleh Tuhan, ia harus setia dan bertanggung jawab dalam melaksanakan tugasnya sebagai gembala yang baik. Roger Robert menyatakan,

Kepada Tuhan dan kepada orang-orang yang saya layani, saya bertanggung jawab untuk setia melaksanakan kewajiban sebagai pelayan Allah (2 Tim. 4:5), kalau kita setia, Tuhan akan memperlihatkan buah atau hasil dari pelayanan kita, akan tetapi yang perlu diutamakan bukan hasil dari pelayanan kita, melainkan kesetiaan kita dalam melayani Tuhan."62

Setiap orang yang telah dipanggil oleh Allah, dan dilayakkan untuk mengambil bagian dalam pekerjaan Tuhan, perlu mengetahui kewajibannya sebagai gembala yang baik yakni, mengenal domba-dombanya demikian juga domba-dombanya mengenal dia, melindunginya dari bahaya,memberi nyawanya bagi domba-dombanya, mencari jika domba-dombanya hilang, memimpin dan membimbing, serta membawanya ke tempat yang tenang.

Demikian juga seorang gembala dalam menjalankan tugasnya, membuka mata dan tetap memandang sejauh mungkin untuk mengawasi datangnya musuh. Sifatnya waspada merupakan sifat yang penting bagi seoran penjaga, demikian pula dombadomba tidak dapat berjalan sendiri dalam mencari rumput makanannya, tetapi membutuhkan seorang pemimpin untuk menuntun ( Mzm. 23:1-6 ). Domba juga tidak dapat mencari makanannya sendiri, dan begitu juga dengan jemaat Tuhan. Oleh karena itu tugas gembala adalah memberi makan kepada domba-dombanya dengan hati yang tulus dan sungguh-sungguh.

Seorang gembala yang baik harus senantiasa menyadari bahwa ia dipilih untuk melayani bukan untuk dilayani. Hal ini sesuai dengan prinsip pelayanan Tuhan Yesus dalam Markus 10:45 "Karna anak manusia datang bukan untuk dilayani melainkan untuk melayani dan untuk memberikan nyawa-nya menjadi tebusan bagi banyak orang." Sedangkan gembala yang tidak baik adalah gembala yang membuarkan, menceraikan, mencari kepentingan diri sendiri, memuliakan diri, mencari untung, memanfaatkan dan

${ }^{61}$ Herman N. Ridderbos, Injil Yohanes Suatu Tafsiran Teologis ( Surabaya: Momentum, 2012 ).

${ }^{62}$ Roger Roberts, Hidup suci Panggilan Bagi Setiap Orang Kristen, ( Bandung: Lembaga Literatur 
hal buruk lainnya. Untuk gembala yang tidak baik, Allah murka dan menghukum mereka.

Berdasarkan penguraian di atas, jelaslah bahwa menjadi gembala yang baik bukanlah pekerjaan yang mudah tetapi suatu pekerjaan berat yang harus dipertanggung jawabkan. Gembala jemaat atau hamba Tuhan yang memiliki panggilan yang sungguhsungguh, kasih dan pengabdian yang tulus, maka Allah akan menganugrahkan kepadanya kemampuan khusus untuk membangun kawanan domba Allah yang dipercayakan untuk digembalakannya. Dengan demikian tujuan pengembalaan akan berhasil.

\section{a. Pelayanan Gereja}

Istilah Gereja berasal dari bahasa Yunani "kuriakos" yang berarti "milik Tuhan." 63 Pengertina ini mengacu pada sekelompok orang yang telah dipanggil keluar dari dunia untuk menjadi milik Allah." ${ }^{\prime 4}$ Kata kuriakos digunakan untuk menunjukan hal-hal seperti tempat atau orang-orang, atau tanah air, atau yang berkaitan dengan kelompok orang yang menjadi milik Tuhan. Istilah lain yang dipakai untuk kata gereja adalah sidang atau jemaat yang diambil dari kata "Ekklesia." Kata ini dipergunakan sebanyak 115 kali dalam Perjanjian Baru dan mempunyai arti "orang yang dipanggil untuk keluar."65

Jadi jelaslah bahwa Gereja merupakan satu perkumpulan atau persekutuan di mana orang-orang yang di dalam-Nya adalah orang-orang yang telah dipanggil keluar dari kegelapan dan telah dikuduskan untuk menjadi milik-Nya, menjadi kawanan sekerja Allah dalam dunia. Dalam uraian di atas jelaslah bahwa Gereja adalah suatu persekutuan, atau persekutuan yang terjadi karena panggilannya Allah bagi orang yang percaya. Alkitab menggambarkan Gereja sebagai umat Allah dalam Wahyu 21:3, digambarkan sebagai satu persekutuan atau perkumpulan dimana Allah hadir dan diam bersama-sama sehingga mereka menjadi umat-Nya. Dalam perjanjian lama yang dimaksud dengan umat Allah ditujukan kepda bangsa Israel, yang dipilih oleh Allah dan dipelihara oleh Allah. Dalam Perjanjian Baru memiliki pengertian yang luas, tetapi Paulus mengungkapkan bahwa jemaat adalah umat Allah yaitu suatu perhimpunan orang-orang yang percaya yang telah ditebus dan yang telah didamaikan dengan Allah." 66 J. Verkuyl mengatakan,

Umat Allah yang dipanggil dari antara segala bangsa, persekutuan orang-orang beriman dari segala zaman dan tempat umat manusia yang baru, persekutuan orang-orang berdosa yang diberi kemampuan, pemberontak-pemberontak yang dibebaskan, orang-orang jahat yang dibenarkan, dan yang kini dipanggil memberitakan kebaikan Dia yang memanggil mereka keluar dari kegelapan kepada terang yang ajaib." 67

Hal ini menunjukkan bahwa Gereja juga merupakan umat yang pribadi menjadi anak Allah, melalui percaya kepada Yesus Kristus, yang bertanggung jawab dalam menggembalakan kawanan domba Allah.

\footnotetext{
${ }^{63}$ Barcalay M. Newman, Kamus Yunani Indonesia (Jakarta: BPK Gunung Mulia 1993). 97

${ }^{64}$ Henry C.Thiessen, Teologi sistematika (Malang: Gandum Mas 1992). 477

${ }^{65}$ Walter Mohr, Anda dan Gereja (Surabaya: YAKIN, ). 7

${ }^{66}$ Donald Guthrie, Teologi Perjanjian Baru, (Jakarta: BPK Gunung Mulia 1992). 77-78

${ }^{67}$ J. Verkuyl, Aku Percaya, (Jakarta: BPK Gunung Mulia, 1977 ).221-222
} 
Dalam Roma 12:4; 1 Korintus 12:4 menjelaskan tentang Gereja sebagai tubuh Kristus, dimana di dalamnya menggambarkan tentang suatu kesatuan atau kebersamaan. "Tubuh Kristus" sebagai tubuh manusia yang mempunyai banyak anggota, saling melengkapi dalam menjalankan tugasnya. Gambaran ini dikaitkan dengan Gereja sebagai anggota tubuh Kristus. Dimana setiap anggota tubuh kristus ikut mengambil bagian dalam pekerjaan-Nya sesuai kecakapan atau karunia yang Allah berikan.

Alkitab dengan jelas mengatakan, bahwa Tuhanlah yang memberikan baik rasulrasul maupun nabi-nabi, baik pemberita-pemberita Injil, gembala-gembala dan pengajar-pengajar untuk melengkapi setiap orang bagi pekerjaan, bagi pembangunan tubuh Kristus (Efs. 4:11-12). Dari ayat ini, maka menjadi tujuan terpenting dari pembelaan adalah supaya jemaat Kristus dibangun.

Kristus menderikan Gereja-Nya tentu mempunyai maksud dan tujuan. Dalam 1 Korints 5:15 dikatakan bahwa Gereja yang hidup adalah Gereja yang tidak hidup bagi dirinya sendiri tetapi bagi Dia yang telah mati dan dibangkitkan. Jemaat atau Gereja yang dibangun Kristus sebagai alat untuk melaksanakan pekerjaan-Nya di dunia ini, Matius 16:18 Yesus berkata "Di atas batu karang ini aku akan mendirikan jemaatku."

Gereja yang didirikan Kristus berfungsi untuk memberitakan Injil kepada semua orang, untuk mengatakan pengampunan dosa, dan pertobatan (Luk.24:27). Hal ini harus menjadi fokus utama pemberitaan dalam gereja. Pada umumnya manusia tidak percaya kepada firman Tuhan dan segala kebenaran yang diwahyukan dalam Alkitab, oleh karena semua orang telah berdosa, maka Injil harus diberitakan agar semua manusia diselamatkan.Tugas pemberita Injil ini ditujukan kepada Gereja sebagai bangsa yang terpilih, imamat yang rajani, umat kepunyaan Allah, yang membawa keluar dari kegelapan kepada terang Tuhan yang ajaib (1 Pet. 2:9). Dengan demikian Gereja dituntut untuk menjadi saksi Kristus ditengah dunia ini. Hal ini disebabkan oleh Karena Gereja Kristen adalah Gereja yang bersaksi, dan setiap orang Kristen terpanggil untuk menjadi seorang saksi.

Gereja sebagai pemberita injil yang bertanggung jawab dalam menggembalakan domba-domba-Nya, maka salah satu tugas Gereja adalah pelayanan (diakonia). Bentuk pelayanan diakonia Yesus maksudkan disini merupakan panggilan Gereja yaitu melayani orang-orang miskin,orang-orang sakit, orang-orang hukuman, orang-orang yang tidak mempunyai tempat tinggal, janda-janda, anak yatim piatu dan lain-lain.

Abineno menjelaskan bahwa "diakonia" adalah perbuatan kasih kepada sesama untuk mewujudkan damai sejahtera (Syalom)."68 Dengan demikian dapat disimpulkan bahwa pelayanan diakonia dalam Gereja mempunyai tujuan mewujudkan damai sejahtera dalam dunia. Hal ini bisa terwujud jika Gereja menjalankan tugasnya dengan baik.

Dalam Gereja terdapat beberapa perbedaan usia yang tidak dapat disatukan. Kebutuhan masing-masing usia berbeda sehingga tidak dapat disatukan. Gembala hendaknya benar-benar mengerti agar tidak mencampur adukkan sehingga tidak terawat dengan baik. Anak-anak masih membutuhkan makanan yang lunak sedangkan orang tua sudah dapat makan makanan yang keras. Demikian juga dengan pelayanan gembala, dia harus mengerti bagaimana firman yang harus diterima oleh anak dan orang tua. Perbedaan itu perlu diketahui agar benar-benar jelas.

Dalam kepercayaan kepada Yesus, Paulus juga membedakan antara bayi rohani dan bayi yang sudah dewasa. Bayi rohani masih membutuhkan bubur sedangkan orang yang sudah dewasa secara rohani tidak membutuhkan bubur lagi melainkan roti. Hal ini harus dimengerti oleh seorang gembala agar benar-benar dapat melakukan pelayanan sesuai dengan firman Tuhan. Orang-orang yang baru bertobat tidak dapat langsung

${ }^{68}$ J. L. Ch. Abineno, Sekitar Diakonia Gereja. (Jakarta: BPK Gunung Mulia, 1976).7 
dipaksakan mengerti doktrin dengan bahasa yang agak sulit melainkan mereka harus dituntun secara sabar agar mereka dapat mengerti maksud dari kepercayaan yang saat itu dimasukinya.

\section{b. Pelayanan Dalam Persekutuan Jemaat}

Gembala jemaat harus memiliki keyakinan akan pengajaran atau Injil yang disampaikan kepada jiwa yang sesat. Karena hanya melalui persekutuan Jemaat, kebenaran Firman Tuhan disampaikan Gembala dan membawa banyak jiwa-jiwa yang datang kepada Tuhan. Seorang gembala jemaat harus memberikan kesaksian keteladanan kepada jemaatnya dan juga kepada orang-orang yang tersesat yakni bukan hanya menyampaikan firman Tuhan tetapi mempraktikkan dalam kehidupannya. Yesus adalah Gembala yang baik. Hati Yesus, yang penuh belaskasih selalu tertuju kepada domba-domba-Nya, Yesus selalu memikirkan dan memperhatikan keselamatan dombadomba-Nya, Dia mencari domba-domba yang hilang dan tersesat, dan membawa mereka ke jalan yang benar.Yesus adalah jalan, kebenaran, dan hidup.

\section{c. Perkunjungan Ke Rumah Jemaat dan Rumah Sakit}

Persekutuan tidak dapat dilepaskan dari gembala. Dia harus selalu hadir dalam kehidupan kelompok domba yang ada dan menjadi panutan bagi domba-domba yang telah menyerahkan dirinya untuk tunduk di bawah kuasa Yesus. Gembala perlu melakukanperkunjungan ke rumah jemaat dan rumah sakit guna mengetahui pergumulan dan kesusahan umat tersebut. Gembala dapat mempelajari situasi yang ada di sekitar jemaatnya agar dapat memberikan saran dan nasihat apa yang dibutuhkan oleh jemaatnya. Mereka merasa ditolong dan diperdulikan. Mereka merasa diterima dan diakui sebagai anak Tuhan yang berharga.

\section{Hasil}

Gembala adalah wakil Allah di dunia. Segala tugas dan kepercayaan dari Tuhan dipercayakan kepada seorang gembala. Gembala memberitakan Injil kepada anak Sekolah Minggu, remaja, pemuda, dewasa dan lansia. Mereka sangat membutuhan kalimat yang menguatkan dan menyejukkan dari dari seorang gembala. Gembala yang baik dapat menggembalakan umat-Nya dengan benar sedangkan gembala yang jahat akan menggembalakan dirinya dan mengutamakan kesenanagan diri sendiri. Kedua jenis gembala ini akan terlihat dari hasil pelayanannya. Hal yang perlu diperhatikan hamba Tuhan adalah pelayanan persekutuan jemaat, perkunjungan ke rumah-rumah dan Rumah sakit adalah tugas yang mulia karena dengan melakukan demikian dapat mengenal keadaan jemaat lebih dalam dan bersahabat.

\section{Kesimpulan}

Sebagaimana seorang petani yang mengharapkan ladangnya dapat menghasilkan untuk menunjang kehidupannya, peternak mendapatkan hasil dari peliharaannya, demikianlah seorang hamba Tuhan atau gembala sangat bersukacita ketika jemaatnya bertumbuh dalam iman dan jumlahnya semakin bertambah. Perintah "Gembalakanlah domba-domba-Ku", tidak dapat diabaikan oleh seorang gembala (hamba Tuhan), karena mengingat dengan segala ancaman yang terjadi, bahkan dengan adanya kemajuan zaman yang telah menggerogoti kehidupan orang percaya yang menyebabkan mereka 
mengalami kemerosotan moral dan iman. Keteladanan hamba Tuhan dalam penggembalaan ialah tugas pokok dan kunci hamba Tuhan gembala) dan wajib dipakai dan dipergunakan. Karena ketika jemaat Tuhan mengalami pertumbuhan iman, mereka akan mempersembahkan hidup dan kepunyaannnya kepada Tuhan dan pelayanan. Sorga dan bumi akan bersukaria bila seorang gembala menunjukkan keteladanan melayani. Dengan demikian, mereka akan setia menanti janji Tuhan. Ia memberi lebih dari yang diminta. Ia adalah Allah yang Maha hadir dalam segala keadaan

\section{Referensi}

Abineno, J. L. Ch., Pengembalaan, Jakarta: BPK Gunung Mulia, 1967

Abineno, J. L. Ch., Sekitar Diakonia Gereja, Jakarta: BPK Gunung Mulia, 1976

Bavink, J.H., Sedjarah Keradjaan Allah Perjajian Baru, Jakarta: BPK Gunung Mulia, 1951

Bons-Strom, M, , Apakah Penggembalaan Itu? Jakarta: BPK Gunung Mulia, 2009

Daugherty, Billy Joe, Kuasa Iman, Bandung: Kalam Hidup, 2004

Fergusen, Sinclair B., Khotba di bukit, Surabaya: Momentum, 1999

Guthrie, Donald, Pengantar Perjanjian Baru (Vol. 1), Surabaya: Momentum, 2012

Guthrie, Donald, Teologi Perjanjian Baru, Jakarta: BPK Gunung Mulia 1992

Hegelberg, Dave, Tafsiran Injil Yohanes pasal 6-12, Yogyakarta: Andi, 2009

Henry, Matthew, Injil Yohanes 12-21, Surabaya: Momentum, 2010

Inggouf, John E., Sekelumit tentang Gembala Sidang, Bandung: Lembaga Literatur Baptis, 1988

Keller, W. Phillip, A Sherperd Looks At Psalm 23, Jakarta: PT Abiyah Pratama, 2008

Kostenberger, Andreas J., Encountering John, Malang: Literatur SAAT Malang, 2015

Kysar, Robert, Injil Yohanes sebagai Cerita, Jakarta: BPK Gunung Mulia, 1995

Leo, Eddy, Iman Seutuhnya, Jakarta: Gunung Sahari, 2005

Mahan, Olifer Mc, Gembala Jemaat Yang Sukses, Jakarta: BPK Gunung Mulia,1994

Mcelrath, W.N dan Billy Mathias Ensiklopedia Alkitab Praktis Edisi Kedua, , (BPK Gunung Mulia, 1978

Milne, Bruce, Yohanes (Lihatlah Rajamu), Jakarta:Yayasan Komunikasi Bina Kasih, 2010

Milne, Bruce, Seri Pemahaman dan Penerapan Amanat Alkitab Masa Kini Yohanes, Jakarta: Yayasan Komunikasi Bina Kasih, 2010

Mohr, Walter, Anda dan Gereja Surabaya: YAKIN

Newman, Barcalay M., Kamus Yunani Indonesia, Jakarta: BPK Gunung Mulia 1993

Oyedepo, David O., Eksplotasi iman, Jakarta: Metanoi, 2008

Price, Friderick K.C., Saran-Saran Praktis untuk Pelayanan yang Berhasil, Jakarta: Imanuel, 1993

Prime, Derek, Alkitab Menjawab Pertanyaan Tentang Iman Kristen, Jakarta: Yayasan Bina Kemusih, 1995

Ridderbos, Herman N., Injil Yohanes Suatu Tafsiran Teologis, Surabaya: Momentum, 2012 Riggs, Ralps M., Gembala Sidang Yang Berhasil, Jakarta: Gandum Mas, 2003

Roberts, Roger, Hidup suci Panggilan Bagi Setiap Orang Kristen, Bandung: Lembaga Literatur Babtis, 2000

Saparman, Menjadi Dewasa Secara Rohani, Bandung: Kalam Hidup, 1997

Sibuea, David Farel, Citra dan Misi Penggembalaan, Jakarta: T.N.P 2004

Sosipater, Karel, Etika Pelayanan, Jakarta: Suara Harapan Bangsa, 2009

Strauss, Richard L., Bagaimana Memahami Kehendak Tuhan, Jakarta: BPK Gunung Mulia, 1999

Tan, John R., Dinamika Pertumbuhan Kristen, Jakarta: Yasinta, 2006

Thiessen, Henry C., Teologi sistematika, Malang: Gandum Mas 1992

Tim Penyusun, Alkitab, (Jakarta: Lembaga Alkitab Indonesia (LAI), 2012 
Tim Penyusun, Ensiklopedi Alkitab Masa Kini (jilid 1 'A-L'), Jakarta: YKBK, 2011 Tim Penyusun, Kamus Besar Bahasa Indonesia Tim Penyusun, Tafsiran Alkitab Masa Kini 2 (Ayub-Maleakhi), Jakarta: YKBK, 2012 Tim Penyusun, Tafsiran Alkitab Masa Kini III (Matius-Wahyu), Jakarta: Yayasan Komunikasi Bina Kasih, 1994

Tim Prima Pena, Kamus Lengkap Bahasa Indonesia, Gitamedia Tong, Stephen, Hidup Kristen Yang Berbuah, Surabaya: Momentum, 2008

Tulluan, Ola,Introduksi PB, Malang: Yayasan Pekabaran Injil Indonesia 1999 Venema, Henk, Injil untuk semua orang, Jakarta: YKBK, 1997

Venema, Henk, Kitab Suci - Untuk Kita, Jakarta: Yayasan Komunikasi Bina Kasih, 2008 Verkuyl, J., Aku Percaya, Jakarta: BPK Gunung Mulia, 1977

Walz, Edgar, Bagaimana mengelolah gereja anda, Jakarta: BPK Gunung Mulia, 2011 Warren, Rick, The Purpose Driven Church, Malang: Gandum Mas

Wiersbe, Warren W., Prioritas Seorang Gembala, Malang: Gandum Mas, 1982 Wongso, Peter, Teologia Penggembalaan, Malang: literatur SAAT, 2007 